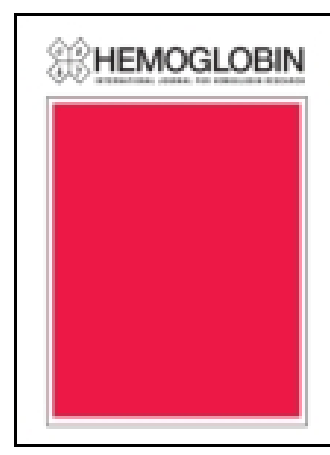

Hemoglobin

international journal for hemoglobin research

ISSN: 0363-0269 (Print) 1532-432X (Online) Journal homepage: http://www.tandfonline.com/loi/ihem20

\title{
Prevalence and Molecular Characterization of $\beta$-Thalassemia in the State of Bahia, Brazil: First Identification of Mutation HBB: c.135delC in Brazil
}

\author{
Silvana F. Fonseca, Jose P. Moura Neto \& Marilda S. Goncalves
}

To cite this article: Silvana F. Fonseca, Jose P. Moura Neto \& Marilda S. Goncalves (2013) Prevalence and Molecular Characterization of $\beta$-Thalassemia in the State of Bahia, Brazil: First Identification of Mutation HBB: c.135delC in Brazil, Hemoglobin, 37:3, 285-290, DOI: 10.3109/03630269.2013.771271

To link to this article: http://dx.doi.org/10.3109/03630269.2013.771271

册 Published online: 21 Feb 2013.

Submit your article to this journal $\pi$

山 Article views: 55

Q View related articles $\asymp$

4 Citing articles: 2 View citing articles 


\title{
SHORT COMMUNICATION
}

\section{PREVALENCE AND MOLECULAR CHARACTERIZATION OF $\beta$-THALASSEMIA IN THE STATE OF BAHIA, BRAZIL: FIRST IDENTIFICATION OF MUTATION HBB: c.135deIC IN BRAZIL}

\author{
Silvana F. Fonseca, ${ }^{1}$ Jose P. Moura Neto, ${ }^{2}$ and Marilda S. Goncalves ${ }^{3,4}$ \\ ${ }^{1}$ Departamento de Pediatric, Universidade de Brasilia (UnB), Brasilia, Brazil \\ ${ }^{2}$ Faculdade de Farmacia, Universidade Federal do Amazonas, Manaus, Brazil \\ ${ }^{3}$ Faculdade de Farmacia, Universidade Federal da Bahia (UFBA), Salvador, Brazil \\ ${ }^{4}$ Laboratory of Pathology and Molecular Biology, "Centro de Pesquisa Gonçalo Moniz," "Fundação \\ Oswaldo Cruz" (FIOCRUZ), Salvador, Brazil
}

$\square \quad \beta$-Thalassemia ( $\beta$-thal) is a hereditary disease with at least 200 known causative molecular defects, with a limited number of distinct mutations predominating in any given population. The Brazilian population is one of the most heterogeneous in the world. Although occurrences of $\beta$-thal in this country have been recognized for a long time and previous studies have shown important regional differences related to the mutational profile, no extensive analysis of mutations of the $\mathrm{HBB}$ gene has been carried out in Brazil. We examined 1011 teenagers from Bahia, a state located in the northeast of Brazil. Hematological data were obtained using automated cell counting, hemoglobin (Hb) profiles were studied by high performance liquid chromatography (HPLC), and DNA was analyzed by automated sequencing. None of the four Mediterranean mutations that are most frequently found in South and Southeast Brazil (HBB: c. $118 G>$ T; HBB: c. 93-21G>A; HBB: c. 92+1G>A; HBB: c. $92+6 T>C$ ), was found to be responsible for thalassemia in the cases that we studied. One heterozygote for a frameshift mutation at codon $44(-C)$ was identified. This is the first study to determine the prevalence and profile of $\beta$-thal in Bahia State. For the first time in Brazil, we report the occurrence of the HBB: c.135delC mutation in the $\beta$-globin gene.

Keywords $\beta$-Thalassemia ( $\beta$-thal), Prevalence, Brazilian population, Hematological and molecular aspects

Received 4 September 2012; Accepted 11 November 2012.

Address correspondence to Professor Silvana Fonseca, SQN 214 Bloco C apt 214 Brasilia DF, Brazil; Tel.: +5561-32227042; Fax: +5561-33281229; E-mail: sfahel@unb.br 
$\beta$-Thalassemia ( $\beta$-thal) is a genetic disorder characterized by mutations on the $\beta$-globin gene $(H B B)$ that lead either to decreased or absent $\beta$-globin chain synthesis. $\beta$-Thalassemia mutations are located throughout the gene, affecting almost every aspect of gene expression. The heterogeneous nature of $\beta$-thal is well known and more than 200 different molecular defects have been characterized (1). This group of diseases represents the most widespread hereditary hemoglobin $(\mathrm{Hb})$ disorders and has been found in practically every population examined. The worldwide distribution of $H B B$ mutant alleles is non random; each ethnic group in which the disease is prevalent has a different spectrum of $H B B$ gene mutations (2-4).

Although occurrences of $\beta$-thal in Brazil have been recognized for a long time, information on prevalence of the disease in this country is scarce and fragmented. Brazil has a multi-ethnic population of almost 200 million people, with a high level of admixture of European, African, Asian and indigenous ancestries that are unevenly distributed over a continental expanse of 8.5 million $\mathrm{km}^{2}(5)$. Brazilians, therefore, form one of the most heterogeneous populations in the world and population composition varies widely between regions $(6,7)$. Consequently, these facts suggest that the incidence of $\beta$-thal should be heterogeneous and that it may be difficult to determine the distribution of $H B B$ gene mutations in this country.

The frequency of $\beta$-thal heterozygotes in South and Southeast Brazil is estimated at around $1.0 \%(8,9)$, with most carriers being of Italian descent. Previous studies in this population showed a high prevalence of mutations of Mediterranean origin, especially HBB: c.118C>T [ codon 39 (C>T); $\beta 39(\mathrm{C} 5)$ $\mathrm{Gln} \rightarrow \mathrm{Stop}$ ], $H B B: \quad$ c.93-21G $>$ A [IVS-I-110 (G>A); $\beta$ nucleotide (nt) 252 $(\mathrm{G}>\mathrm{A})$ ], $H B B:$ c.92+1G>A [IVS-I-1 $(\mathrm{G}>\mathrm{A}) ; \beta$ nt $143(\mathrm{G}>\mathrm{A})]$ and $H B B$ : c. $92+6$ T $>$ C $[$ IVS-I-6 $(\mathrm{T}>\mathrm{C}) ; \beta$ nt $148(\mathrm{~T}>\mathrm{C})](10-12)$.

The $\beta$-thal prevalence in North and Northeast Brazil is still undetermined and the few studies from this region to report molecular aspects showed a higher prevalence of $H B B: c .92+6 \mathrm{~T}>\mathrm{C}$ and $H B B: c .92+1 \mathrm{G}>\mathrm{A}$. However, the HBB: c.92+5G>C [IVS-I-5 (G>C); $\beta$ nt $147(\mathrm{G}>\mathrm{C})$ ], an Indian-Asian mutation mostly described on the Indian subcontinent, Pakistan, Sri Lanka, Mauritius Island, Oman and other part of the Middle East, has also been found (13-15).

The present study aimed to identify the prevalence and variability of $\beta$-thal in the Brazilian state of Bahia, located in the northeastern region of the country, where about $80.0 \%$ of the population is Black or mixed, identifying the $\beta$-thal mutations, concentration of $\mathrm{Hb}$, mean cell volume (MCV), mean cell $\mathrm{Hb}(\mathrm{MCH}), \mathrm{Hb} \mathrm{A}_{2}$ and $\mathrm{Hb}$ F values, related to the disease. This is the first study designed to analyze this kind of thalassemia in the population of Bahia State, Brazil.

The sample group consisted of 1011 male adolescents aged from 17 to 19 years, who presented at the Army Selection Center in Salvador, Bahia, Brazil in 2003, and were exempted from military service due to excess of applicants. 
The present study was carried out after approval from the Research Ethics Committee of the "Centro de Pesquisa Gonçalo Moniz of the Fundaçao Oswaldo Cruz" (CPqGM/FIOCRUZ), and followed the ethical principles established by the resolution number 196/96 of the Brazilian National Health Council, as well as the ethical principles of the Helsinki Declaration of 1964, as revised by the World Medical Association in 2000. All participants agreed to participate in the study, and signed an informed consent declaration.

Blood samples were drawn by venipuncture using EDTA as an anticoagulant. Hematological data were obtained using an automated cell counter (Coulter Counter T890; Beckman Coulter, Brea, CA, USA), Hb profiles were studied by the high performance liquid chromatography (HPLG) technique using the VARIANT ${ }^{\mathrm{TM}}$ II, $\beta$-Thalassemia Program (Bio-Rad Laboratories, Hercules, CA, USA). The two cases that presented with $\mathrm{Hb} \mathrm{\textrm {A } _ { 2 }}$ levels greater than or equal to $3.5 \%$, independently of MCV and MCH, had the most extensively researched $\beta$-thal mutations. DNA sequencing was performed using an automated DNA sequencer (ABI PRISM® 3100 Automatic Genetic Analyzer; Applied Biosystems, Foster City, CA, USA), with the BigDye ${ }^{\circledR}$ Terminator v3.1 Cycle Sequencing Kit (Applied Biosystems). The DNA sequencing was repeated three times for each experiment, using different polymerase chain reaction (PCR) products in order to confirm the findings. The techniques were developed at the Laboratory of Pathology and Molecular Biology of the "Centro de Pesquisa Gonçalo Moniz" of the "Fundação Oswaldo Cruz" (CPqGM/FIOCRUZ).

One individual heterozygous for a $\beta$-thal mutation was identified (prevalence of $0.1 \%$ ). Despite the sample size being relatively small, the low prevalence of $\beta$-thal heterozygotes are in agreement with the data related to the ethnic origins of the Bahian population ( $80.0 \%$ of African descent), and with the prevalence estimated through the absence, in the state of Bahia, of newborns homozygous for $\beta$-thal mutations identified through newborn screening $(16,17)$.

Table 1 shows hematological and molecular data related to both the studied individuals. The subjects were unable to give information regarding ancestry.

Significantly, in the approximately 100-year period from 1872 to 1975 , Brazil received a large number of immigrants from Europe and other parts of the world (34.0\% Italians, 29.0\% Portuguese, 14.0\% Spanish, 5.0\% Japanese, $4.0 \%$ Germans, $2.0 \%$ Lebanese and Syrians, and $12.0 \%$ others) (5).

The state of Bahia was the site at which the Portuguese first arrived in Brazil in 1500. Also, the African slave trade had Bahia as one of its main receiving points in Brazil. In the 18th century, the region was attacked by the Dutch, who were later expelled by the Portuguese. Driven out of Portugal, many Jews also settled in northeastern Brazil in the 17 th century. For about a 
TABLE 1 Hematological and Molecular Characteristics of the Two Cases Who Presented Hb $\mathrm{A}_{2}$ Levels Greater Than or Equal to $3.5 \%$

\begin{tabular}{lcc}
\hline Parameters & Case 1 & Case 2 \\
\hline Sex-Age (years) & $\mathrm{M}-17$ & $\mathrm{M}-18$ \\
$\mathrm{RBC}\left(10^{12} / \mathrm{L}\right)$ & 5.75 & 5.18 \\
$\mathrm{Hb}(\mathrm{g} / \mathrm{dL})$ & 12.3 & 13.0 \\
$\mathrm{PCV}(\mathrm{L} / \mathrm{L})$ & 0.39 & 0.39 \\
$\mathrm{MCV}(\mathrm{fL})$ & 68.6 & 76.1 \\
$\mathrm{MCH}(\mathrm{pg})$ & 21.4 & 25.2 \\
$\mathrm{Hb} \mathrm{A}(\%)$ & 6.1 & 5.7 \\
$\mathrm{Hb} \mathrm{F}(\%)$ & 1.7 & 7.6 \\
Mutation & $H B B:$ c.135delC & Codon $2(\mathrm{C}>\mathrm{T})$ \\
\hline
\end{tabular}

century, Bahia retained the title of the most important seaport in the southern hemisphere, carrying out heavy trade with Europe, Asia and Africa. Added to this, from the years of World War I and into the 1920s and 1930s, further Jewish immigrants from Eastern and Western Europe and the Middle East formed structured communities in Salvador, Bahia (18).

The four Mediterranean mutations most often found in previous studies in Brazil (HBB: c.118C $>\mathrm{T}$; $H B B$ : c.93-21G>A; HBB: c.92+1G>A; $H B B$ : c. $92+6 \mathrm{~T}>\mathrm{C}$ ) were not detected in the current analysis. The HBB: c.135delC had never been previously reported in the Brazilian population. It has been frequently reported in Kurdish Jews, and rarely in various populations around the Mediterranean Sea and the Middle East. HBB: c.135delC homozygotes have a clinical picture of severe thalassemia, while heterozygotes show light anemia with important microcytosis and hypocromia, which were also observed in our case (19-22).

Figure 1 shows the electropherograms of the subject who was heterozygous for the $H B B$ : c.135delC [codon $44(-\mathrm{C})$; TCC $\left.(\operatorname{Ser})>\mathrm{TC}-\left(\beta^{0}\right)\right]$. For each electropherogram, a separate PCR was performed.

In the second individual, who showed elevated levels of $\mathrm{Hb} \mathrm{A}_{2}$, we identified only the polymorphism $\mathrm{C}>\mathrm{T}$ at codon 2 , which has been identified in patients with $\beta$-thal alleles and also in normal individuals without thalassemia mutations $(23,24)$. Sonati et al. reported an 8-year-old Brazilian girl with sickle cell- $\beta$-thal, who had the $H B B$ : c. $92+6 \mathrm{~T}>\mathrm{C}$ [IVS-I-6 $(\mathrm{T}>\mathrm{C})$ ] mutation associated with the $\mathrm{C}>\mathrm{T}$ polymorphism at codon 2 . The DNA sequencing of the patient's mother showed her to be heterozygous for the HBB: c.92+6T $>\mathrm{C}$ and homozygous for the $\mathrm{C}>\mathrm{T}$ polymorphism at codon 2 (25).

The HBB: c.135delC mutation demonstrates an unusual component in the genetic makeup of the Brazilian population, supporting the high degree miscegenation. To disclose the real prevalence and the full spectrum of $\beta$-thal mutations in Brazil, it would be necessary to analyze individuals from all over the country. 


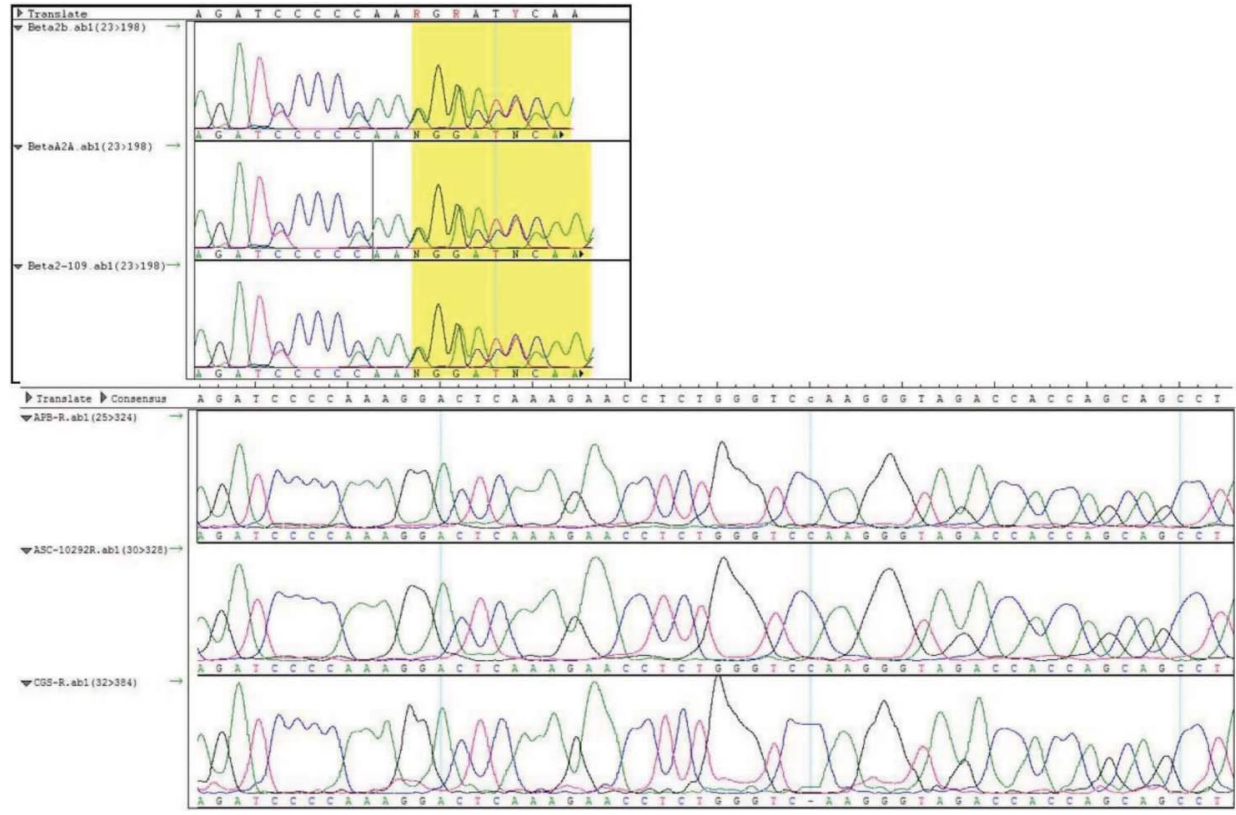

FIGURE 1 Electropherogram scans showing the wild type (down) and the HBB: c.135delC (up) sequencing of the $\beta$-thal patient (case 1).

Declaration of Interest: The authors report no conflicts of interest. The authors alone are responsible for the content and writing of this article.

\section{REFERENCES}

1. Rund D, Rachmilewitz E. $\beta$-Thalassemia. N Engl J Med. 2005;353(11):1135-1146.

2. Hardison RC, Chui DHK, Giardine B, et al. HbVar: a relational database of human hemoglobin variants and thalassemia mutations at the globin gene server. Hum Mutat. 2002;19(3):225-233 (http://globin. cse.psu.edu).

3. Patrinos GP, Giardine B, Riemer C, et al. Improvements in the HbVar database of human hemoglobin variants and thalassemia mutations for population and sequence variation studies. Nucleic Acids Res. 2004;32(Database issue):D537-D541 (http://globin.cse.psu.edu).

4. Giardine B, van Baal S, Kaimakis $\mathrm{P}$, et al. HbVar database of human hemoglobin variants and thalassemia mutations: 2007 update. Hum Mutat. 2007;28(2):206 (http://globin.cse.psu.edu).

5. Pena SDJ, Bastos-Rodrigues L, Pimenta JR, Bydlowsk SP. DNA tests probe the genomic ancestry of Brazilians. Braz J Med Biol Res. 2009;42(10):870-876.

6. Carvalho-Silva DR, Santos FR, Rocha J, Pena SDJ. The phylogeography of Brazilian Y-chromossome lineages. Am J Hum Genet. 2001;68(1):281-286.

7. Zembrzuski VM, Callegari-Jacques SM, Hutz MH. Application of an African ancestry index as a genomic control approach in a Brazilian population. Ann Hum Genet. 2006;70(6):822-828.

8. Freitas EM, Rocha FJ. Detection of $\beta$-thalassemia heterozygotes among Caucasians from Porto Alegre, RS, Brazil. Braz J Genet. 1983; 6(1):185-188.

9. Ramalho AS, Silva RBP, Teixeira RC, Compri MB. Hemoglobin screening: response of a Brazilian community to optional programs. Cad Saúde Pública. 1999;15(3):591-595. 
10. Fonseca SF, Kerbauy J, Escrivão C, et al. Genetic analysis of $\beta$-thalassemia major and $\beta$-thalassemia intermedia in Brazil. Hemoglobin. 1998;22(3):197-207.

11. Reichert VC, de Castro SM, Wagner SC, de Albuquerque DM, Hutz MH, Leistner-Segal S. Identification of $\beta$-thalassemia mutations in South Brazilians. Ann Hematol. 2008;87(5):381-384.

12. Fernandes AC, Shimmoto MMA, Furuzawa GK, Vicari P, Figueiredo MS. Molecular analysis of $\beta$ thalassemia patients: first identification of mutations HBB:c.93-2A>G and HBB:c.114G>A in Brazil. Hemoglobin. 2011;35(4):358-366.

13. Araújo AS, Silva WA, Leão SAC, et al. A different molecular pattern of $\beta$-thalassemia mutations in northeast Brazil. Hemoglobin. 2003;27(4):211-217.

14. Bezerra MAC, Santos MNN, Araújo AS, Gomes YM, Abath FGC, Bandeira FMGC. Molecular variations linked to the grouping of $\beta$ - and $\alpha$-globin genes in neonatal patients with sickle cell disease in the state of Pernambuco, Brazil. Hemoglobin. 2007;31(1):83-88.

15. Da Silveira ZML, Barbosa MV, Fernandes TAAM, et al. Characterization of $\beta$-thalassemia mutations in patients from the state of Rio Grande do Norte, Brazil. Genet Mol Biol. 2011;34(3):425-428.

16. Adorno EV, Couto FD, Moura Neto JP, et al. Hemoglobinopathies in newborns from Salvador, Bahia, Northeast Brazil. Cad Saude Publica. 2005;21 (1):292-298.

17. Amorim T, Pimentel H, Fontes MIMM, Purificacao A, Lessa P, Boa-Sorte, N. Evaluation of a Neonatal Screening Program of Bahia from 2007 to 2009. Lessons of hemoglobinopathies. Gaz Med Bahia. 2010;80(3):10-13.

18. Lesser, JH. Pawns of the powerful: Jewish immigration to Brazil 1904-1945. Ph.D. Dissertation, New York University, New York, USA, 1989.

19. Chook I, Daoud BB, Mellouli F, et al. Contribution to the description of the $\beta$-thalassemia spectrum in Tunisia and the origin of mutation diversity. Hemoglobin. 2004;28(3):189-195.

20. Fattoum S, Messaoud T, Bibi A. Molecular basis of $\beta$-thalassemia in the population of Tunisia. Hemoglobin. 2004;28(3):177-187.

21. Eshghi P, Zadeh-Vakili A, Rashidi A, Miri-Moghadam E. An unusually frequent $\beta$-thalassemia mutation in an Iranian Province. Hemoglobin. 2008;32(4):387-392.

22. Abuzenadah AM, Hussein IM, Damanhouri GA, et al. Molecular basis of $\beta$-thalassemia in the western province of Saudi Arabia: identification of rare $\beta$-thalassemia mutations. Hemoglobin. 2011;35(4): 346-357.

23. Orkin SH, Kazazian HH Jr, Antonarakis SE, et al. Linkage of $\beta$-thalassemia mutations and $\beta$-globin gene polymorphisms with DNA polymorphisms in human $\beta$-globin gene cluster. Nature. 1982;296 (5858):627-631.

24. Atweh G, Forget BG. Identification of a $\beta$-thalassemia mutation associated with a novel haplotype of RFLPs. Am J Hum Genet. 1986;38(6):855-859.

25. Sonati MF, Taeda J, Kimura EM, Costa FF, Luzzato L. Mild clinical expression of S- $\beta$ thalassemia in a Brazilian patient with the $\beta^{+}$IVS-I-6 $(\mathrm{T} \rightarrow \mathrm{C})$ mutation. Genet Mol Biol. [online]. 1998;21 (4):[cited 2013-01-22] (available from: http://www.scielo.br/scielo.php?script=sci_arttext\&pid=S1415$7571998000400002)$, 